Acta Universitatis Wratislaviensis No 3705

PRAWO CCCXX

Wrocław 2016

DOI: $10.19195 / 0524-4544.320 .8$

JOANNA SIEKIERA

Victoria University of Wellington

e-mail: joanna.siekiera@vuw.ac.nz

\title{
Rola sądów administracyjnych w nowozelandzkim systemie prawnym
}

\section{Wprowadzenie}

Sądownictwo administracyjne zajmuje w Nowej Zelandii wysoką pozycję zarówno pod względem prawnym, jak i według opinii publicznej ${ }^{1}$. Gałąź tej dyscypliny prawa publicznego jest rozbudowana, dotyka wielu dziedzin życia prywatnego i wspólnotowego, regulując prawnie liczne uprawnienia oraz obowiązki nowozelandzkich osób fizycznych i prawnych. $Z$ drugiej strony, nie bez znaczenia pozostaje fakt ogromnego wpływu norm administracyjnych wprowadzanych poprzez decyzje organów administracyjnych bądź orzeczenia sądów administracyjnych na obywateli. Nowozelandczycy są nierzadko związani dyskrecjonalną władzą administracji, co wpływa na ich wysoką świadomość prawną. Niewątpliwie sprawnie funkcjonująca administracja publiczna oraz sądownictwo administracyjne Nowej Zelandii przekłada się na fakt, iż państwo to utrzymuje poziom życia obywateli będący jednym z najwyższych na świecie. Rozwiązania systemowe zapewniają stabilność i pewność działań organów państwowych, także podczas światowych kryzysów. Nowozelandzki porządek prawny nie jest dostatecznie poznany ani zbadany na kontynencie europejskim. W związku z odległościami geograficznymi, wyższym poziomem produktu krajowego brutto, wskaźnikiem

${ }^{1}$ Autorka przebywała w Nowej Zelandii od lutego do maja 2015 r. na wizytacji naukowej na zaproszenie Wydziałów Prawa University of Auckland oraz University of Waikato. Zarówno pracownicy naukowi, jak i zwykli rezydenci państwa podkreślali znaczącą rolę administracji oraz sądownictwa administracyjnego w życiu codziennym; Podstawą opracowania są rozmowy autorki z prof. Tonym Angelo z Victoria University of Wellington (4.03.2015), prof. Treasą Dunworth z University of Auckland (25.02.2015) oraz prof. Chrisem Gallavinem z Canterbury Univeristy (23.03.2015). 
importu i eksportu różniącym się w poszczególnych regionach, a także odmiennymi zbiorami norm prawnych nie porównuje się rozwiązań nowozelandzkich i europejskich. Jest to wszak luka badawcza, którą należy wypełnić. Przykład nowozelandzkiego dążenia do niepodległości, w tym do suwerenności w stanowieniu i egzekwowaniu prawa, stanowi fenomen, na którym mogą wzorować się inne państwa. Bynajmniej nie dotyczy to jedynie wyspiarskich państw regionu Pacyfiku Południowego, dla których nowozelandzkie rozwiązania są wzorem do naśladowania ${ }^{2}$. Unii Europejskiej prawo administracyjne w Nowej Zelandii może służyć za praktyczny wzorzec, jak osiągnąć pożądany przez państwo wysoki poziom funkcjonowania sądownictwa administracyjnego.

\section{System prawny Nowej Zelandii}

Do zrozumienia pozycji, jaką zajmują w nowozelandzkim systemie prawnym trybunały administracyjne (administrative tribunals) konieczne jest nakreślenie przynajmniej głównych zasad tego „egzotycznego”, z polskiej perspektywy, porządku prawnego, a także historii państwowości wraz z ukazaniem czynników polityczno-prawnych mających znaczący wpływ na kształtowanie narodu. Nowozelandzki system prawny stanowi wypadkową dwóch kultur prawnych: anglosaskiej (common law) oraz polinezyjskiej, z której zaczerpnął katalog norm wywodzących się z tradycyjnych wierzeń religijnych ludów Polinezji. Na styku dorobku Imperium Brytyjskiego oraz nowo powstałego narodu nowozelandzkiego $^{3}$ zbudowano system polityczny, który w wielu miejscach odwołuje się do tradycji Maorysów. Prawo zwyczajowe wraz z wierzeniami ludności autochtonicznej wciąż ma odzwierciedlenie w normach stanowionych. Także w XXI w. przekładają się one na precedensowe akty sądów oraz propozycje ustawodawcze przedstawicieli parlamentu w Wellington ${ }^{4}$.

2 Więcej na temat prawno-ekonomicznych rozwiązań systemowych Nowej Zelandii, dzięki którym państwo to uważa się za wzór dla biednych, rozwijających się wyspiarskich państw Oceanu Spokojnego zob. J. Siekiera, Nowa Zelandia jako regionalny wzór dobrobytu dla rozwijajacych się państw Pacyfiku Poludniowego, [w:] Australia, Nowa Zelandia - polityka dobrobytu, red. K.A. Kłosiński, P. Rubaj, Lublin 2014.

3 Nowa Zelandia uzyskała suwerenność w roku 1947, w którym przyjęto postanowienia Statutu Westminsterskiego 1931 (The Statute of Westminster). Ten zespół przepisów ratyfikowano dopiero 16 lat po jego przyjęciu z powodu oporu części społeczeństwa przed formalnym zerwaniem więzi z metropolią, a zatem ostatecznym zerwaniem z epoką kolonialną. Więcej na ten temat S. Bożyk, System konstytucyjny Nowej Zelandii, Warszawa 2009; G. Palmer, Unbridled Power: An Interpretation of New Zealand's Constitution \& Government, Oxford 1987.

${ }^{4}$ Wywiad autorki z przedstawicielem Trybunału Waitangi, rozstrzygającym o zastosowaniu zasad uznanych na mocy Traktatu z Waitangi, Nyenyezim Siameją, w Wellington 11.03.2015. Co należy podkreślić, Trybunał Waitangi jest szczególnym przykładem trybunału administracyjnego. 
Państwo to, z uwagi na relatywnie krótki okres niezależności od monarchii Brytyjskiej, a także kulturę prawną pozostającą w orbicie porządku common law, posiada zróżnicowany katalog źródeł prawnych. Na prawne podstawy ustroju państwa Aotearoa ${ }^{5}$ składa się szereg dokumentów różnej rangi i pochodzenia. Nowa Zelandia nie posiada konstytucji skodyfikowanej w jednym akcie o najwyższej mocy prawnej. Oprócz ważnego z punktu widzenia państwowości Traktatu z Waitangi z 1840 r. ${ }^{6}$ oraz Ustawy Konstytucyjnej z 1986 r. ${ }^{7}$ do źródeł prawa konstytucyjnego włączono inne normy. Oprócz nowozelandzkiego ustawodawstwa są to także akty przyjęte jeszcze przez parlament w Londynie ${ }^{8}$. Ważną częścią systemu prawa są wciąż prerogatywy monarchy. Należy pamiętać, iż Nowa Zelandia, choć jest samowładnym i całowładnym podmiotem prawa międzynarodowego, wchodząc w skład organizacji The Commonwealth of Nations (Wspólnota Narodów), uznaje za głowę kraju brytyjskiego monarchę. Orzecznictwo sądów, głównie sądów administracyjnych (najliczniejszych w systemie), a także konwenanse konstytucyjne ${ }^{9}$ zamykają katalog źródeł prawa w Nowej Zelandii (Wyspy kojarzą się z Wielką Brytanią).

Stanisław Bożyk słusznie zauważa, iż system prawny Nowej Zelandii: ,[...] cechuje daleko idąca stabilność rozwiązań prawnoustrojowych. Jest to [...] konsekwencja [...] nawiązania do zasad i konstrukcji brytyjskiego systemu rządów parlamentarno-gabinetowych" 10 . Co należy jednoznacznie podkreślić, za suwerena uważa się naród nowozelandzki, a nie monarchę brytyjskiego. Głowa państwa w Wielkiej Brytanii sprawuje jedynie funkcje o charakterze ceremonialnym, podczas gdy reprezentantem monarchy jest gubernator generalny ${ }^{11}$.

Jego cechą specyficzną jest posiadanie własnej jednostki kierowniczej oraz unikatowy zakres spraw, którymi się zajmuje. $Z$ tych powodów jest to zupełnie wyjątkowy organ, chociaż sprawowane przez niego funkcje i jurysdykcja nie są obce pozostałym państwom Południowego Pacyfiku.

${ }^{5}$ Kraina Długiej Białej Chmury to oficjalna nazwa Nowej Zelandii w jej drugim z oficjalnych języku państwowym, tj. maoryskim.

${ }^{6}$ Układ pokojowy zawarty między wodzami maoryskimi a brytyjskimi kolonizatorami stanowi bez wątpienia podwalinę państwowości Nowej Zelandii. Jest to także najbardziej kontestowany dokument w dziejach tego państwa, gdyż od początku swego istnienia zakładał nierówność jego sygnatariuszy. Strona brytyjska celowo wydała akt w dwóch różnych językach autentycznych, podczas gdy Maorysi przyjęli go zgodnie z zasadą dobrej wiary. Autochtoni nie posiadali żadnej instytucji odwoławczej ani rzecznika oficjalnie nadanych praw. Dopiero wraz z powołaniem Trybunału Waitangi w 1975 r. możliwe było wyczekiwane rozstrzygnięcie historycznych żądań Maorysów przeciwko Europejczykom. Traktat $\mathrm{z}$ Waitangi funkcjonuje w obecnym porządku prawnym jako Treaty of Waitangi Act 1975 (Traktat z Waitangi) z 10 października 1975 r. (Public Act 1975 No 114).

7 Constitutional Act 1986 (Ustawa Konstytucyjna) z 13 grudnia 1986 r. (Public Act 1986 No 114).

8 Mowa tu m.in. o słynnej Magna Carta z 1215 roku.

9 Do konwenansów konstytucyjnych zalicza się m.in. indywidualną odpowiedzialność szefów ministerstw oraz zbiorową odpowiedzialność rządu. Szerzej na ten temat w Encyklopedii Nowej Zelandii: http://www.teara.govt.nz/en/constitution/page-2 (dostęp: 2.11.2015); strona internetowa rządu Nowej Zelandii: http://cabinetmanual.cabinetoffice.govt.nz/node/68 (dostęp: 2.11.2015).

10 S. Bożyk, op. cit., s. 55.

11 Art. 3 Ustawy Trybunału Konstytucyjnego 1986; ibidem, s. 15. 
Do zrealizowania wyjściowego założenia, tj. ukazania istotnej roli trybunałów administracyjnych w systemie prawnym Nowej Zelandii, niezbędne jest przedstawienie struktury sądownictwa. Sądy nowozelandzkie mają przypisanych wiele różnych ról, w tym przede wszystkim egzekwowanie norm prawa karnego, rozwiązywanie sporów cywilnych, ochronę praw jednostek, zapewnianie w każdej sprawie, by instytucje rządowe działały w granicach prawa, skończywszy na funkcji eksplanatoryjnej prawa. W rozwiązywaniu sporów sądy rozważają dowody na wszystkich stadiach postępowania, interpretują prawo w takim zakresie, jaki odnosi się do tych dowodów, a następnie wydają wyrok. Na sądowy system Nowej Zelandii składają się Sąd Najwyższy (Supreme Court), Sąd Apelacyjny (Court of Appeal), Wysoki Trybunał (High Court) ${ }^{12}$, 57 Sądów Okręgowych, Sądy Rodzinne, Sądy dla Młodocianych, Sądy Ekologiczne, Sądy Pracy, Sądy Koronera oraz Maoryski Sąd Ziemski ${ }^{13}$. Funkcjonują one w świetle podstawowych dla państw anglosaskiego obszaru polityczno-kulturowego instytucji prawnie wiążącego precedensu, zasady rządów prawa czy niezawisłości sędziowskiej.

\section{Prawo administracyjne w Nowej Zelandii}

Sądownictwo administracyjne jest łącznikiem pomiędzy sądami a zwykłą administracją, ale przede wszystkim w płaszczyźnie pionowej stanowi pomost łączący obywateli z organami państwa. Rozwój sądów administracyjnych w wielu krajach związany jest ze wzrostem kompetencji publicznych państwa względem ludności. Ten rozszerzający się wymiar działalności urzędów państwa należy upatrywać w złożoności społeczeństwa i zachodzących w nim procesach. Powiązana jest z tym także większa świadomość społeczna przysługujących praw oraz obowiązków obywateli. Przekłada się to z kolei na otwarte żądanie przestrzegania sprawiedliwości społecznej, sprawnego funkcjonowania administracji publicznej czy bardziej efektywnego, tj. mniej sformalizowanego, działania urzędów ${ }^{14}$.

W Nowej Zelandii państwo od dłuższego czasu wykonuje funkcje, które do niedawna były, a w wielu krajach wciąż są, w rękach instytucji prywatnych. Można było zatem oczekiwać, iż sądownictwo administracyjne już od samego po-

12 W języku potocznym Supreme Court oraz High Court thumaczy się jako Sąd Najwyższy. $\mathrm{Z}$ prawnego punktu widzenia jednak nie są to terminy równoznaczne. Pierwszy z trybunałów stoi na czele całego systemu jurysdykcji i odpowiada za jego spójność. High Court natomiast posiada kompetencje w sprawach karnych i cywilnych, orzekając w I instancji bądź jako instytucja odwoławcza od danej kategorii sądów czy trybunałów.

13 Szerzej na temat struktury nowozelandzkiego wymiaru sprawiedliwości zob. stronę internetową Ministerstwa Sprawiedliwości: http://www.justice.govt.nz/courts (dostęp: 2.11.2015).

14 Por. J.L. Smith, The Role and Importance of Administrative Tribunals, Canadian Council of Administrative Tribunals Conference, Toronto June 21, 2004; Encyklopedia Nowej Zelandii: http:// www.teara.govt.nz/en/1966/administrative-tribunals (dostęp: 2.11.2015). 
czątku sprawowania swego zwierzchnictwa będzie istotnym elementem systemu prawnego. Tak się jednak nie stało. Związane było to z wcześniejszą interwencją państwa, która wielokrotnie przyjmowała formę nacjonalizacji czy rozdrobnionej (biurokratycznej) administracji. Dopiero od lat 30. XX w. wprowadzono rządowe rozporządzenia dotyczącego gospodarki poza sektorem publicznym ${ }^{15}$, które sprawiły, że niezależne trybunały administracyjne zaczęly odgrywać szczególnie ważną rolę. Organy te postrzegać należy bowiem bardziej jako agencje administracyjne aniżeli organy sądowe. Wykonują one funkcje określane mianem quasi-sądowych (quasi-judical), stąd też są odmiennie względem sądów traktowane na gruncie nowozelandzkiego orzecznictwa. Trybunały administracyjne wyposażone zostały bowiem w cechy zbliżone do działania sądów, mimo że podejmowane przez nie decyzje mogą być zaskarżane bezpośrednio do sądów albo do innych organów. W szerokim zakresie spraw trybunały administracyjne nie podlegają kontroli sądowej, pozostając w granicach własnej jurysdykcji.

Jak już zostało wcześniej wskazane, sądownictwo administracyjne można traktować jako pomost łączący sądy i administrację. Posiada ono bowiem cechy każdego z nich. Naturalnie ich członkowie, funkcje, a także procedury obowiązujące w organach administracyjnych oraz sądach różnią się od siebie znacząco. W Nowej Zelandii prawie wszystkie sądy administracyjne posiadają uprawnienia komisji śledczych. Ich wspólną cechą jest możliwość identyfikacji członków w przeciwieństwie do anonimowości administracji. Drugą cechą szczególną jest obowiązek organów administracyjnych rozstrzygania spraw na drodze sądowej, a nie administracyjnej, jak w Polsce, w tym obowiązek wysłuchania stron. Kompetencje te obejmują także wolność od ingerencji rządu przy wydawaniu decyzji, chociaż w niektórych przypadkach sądy muszą mieć na uwadze prerogatywy polityki rządu. Organy te, chociaż mogą angażować się w proces podejmowania decyzji politycznych, nie podlegają wszak kontroli ze strony władzy wykonawczej. $\mathrm{Z}$ drugiej jednak strony postępowanie sądów administracyjnych jest mniej, często o wiele mniej formalne niż pozostałych sądów ${ }^{16}$.

Zasady prawa administracyjnego pokrywają się z tymi przyjętymi w większości prawodawstw europejskich. Do głównych cech porządku prawnego Nowej Zelandii należy działanie administracji publicznej w ramach prawa stanowionego, rozsądne (proporcjonalne co do celu), a wreszcie sprawiedliwie funkcjonowanie zgodnie z sentencją ex cequo et bono. To właśnie przez tę ostatnią właściwość

15 Mowa głównie o The Finance Act of 1936 oraz The Regulations Act 1936 mających wpływ na poprawę gospodarki Nowej Zelandii podczas spadku koniunktury w okresie międzywojennym. Szerzej na ten temat R. Carter, Regulations and Other Subordinate Legislative Instruments: Drafting, Publication, Interpretation and Disallowance, Wellington 2010.

16 Sądy administracyjne nie są bowiem związane zwykłymi regułami postępowania dowodowego. Szerzej na ten temat: P.A Joseph, Constitutional \& Administrative Law in New Zealand, Wellington 2014; The New Zealand Legal System: A guide to the constitution, government and legislature of New Zealand, Ministry of Justice, Wellington 2014. 
administracja Nowej Zelandii kieruje się zawsze w wydaniu swoich decyzji koniecznością osiągnięcia korzyści dla obywatela swojego państwa ${ }^{17}$. Sądy administracyjne ustanowione zostały celem wykazania, czy dany przypadek, stan prawny bądź faktyczny nie narusza praw obywatelskich. Warto podkreślić, iż kompetencja ta jest przyznana wyłącznie sądom administracyjnym. Także spory dotyczące świadczeń socjalnych rozwiązywane są przez sądownictwo administracyjne. Jest to interesujące z punktu widzenia stron ewentualnego sporu. Wszak państwo reprezentuje interesy monarchii, co może budzić zarzut, jakoby polityka sprawiedliwości sądów była wielce dyskusyjna. W 2010 r. powołano specjalną komisję rządową odpowiedzialną za monitorowanie oraz opiniowanie projektów ustaw regulujących materię prawa administracyjnego ${ }^{18}$. Powszechnie mówi się w nowozelandzkiej doktrynie prawa administracyjnego o waloryzacji, prawnym wartościowaniu katalogu spraw sądowych, gdyż te bowiem o najniższym znaczeniu (tzw. drobne sprawy) prowadzone są przez sądy administracyjne. Zdecydowanie stanowią one najliczniejszą grupę postępowań, od których rozwiązań często zależy poprawa sytuacji obywateli. Ponadto zakres działania sądownictwa administracyjnego w Nowej Zelandii jest zwykle bardzo wąski, specjalistyczny. Dysponują one pomocą biegłych specjalistów z wielu dziedzin, dzięki czemu są one w stanie rzeczowo rozstrzygnąć wiele sporów czy wydać decyzje administracyjne. Zwykłe sądy nie orzekłyby bowiem w sposób oczekiwany ${ }^{19}$.

Sądy administracyjne na terytorium Nowej Zelandii można podzielić na te, które podejmują ostateczną decyzję względem osoby indywidualnej, a zatem sprawy mogące stać się przedmiotem późniejszego odwołania oraz te, które są ograniczone w swej kompetencji jedynie do wyjaśnienia stanu faktycznego czy prawnego. W tym drugim przypadku postępowanie nie skończy się na wstępnym etapie. Składa się z fazy wyjaśnienia oraz wydania orzeczenia. Takie postępowanie wyjaśniające jest bardzo powszechne i w istocie ważne w porządku brytyjskim. Posiada ono jednak mniejsze znaczenie w Nowej Zelandii. Za przykład mogą tu posłużyć przewidziane ustawami komisje śledcze, a także przesłuchanie kandydatów na ministrów ${ }^{20}$.

17 Report of the Controller and Auditor-General on Public Consultation and Decision-making in Local Government, Wellington 1998.

18 Więcej na temat działalności The Public and Administrative Law Committee zob. strona internetowa New Zealand Law Society: https://www.lawsociety.org.nz/about-nzls/law-reform/publicand-administrative-law-committee (dostęp: 2.10.2015).

19 P.A. Joseph, Exploratory Questions in Administrative Law, „New Zealand Universities Law Review” 2012, nr 25 (1), s.73-102; Where are Recent Decisions taking Administrative Law Conceptually? Legislative Council Chamber, Parliament Buildings, Wellington, New Zealand: Administrative Law - the public law scene in 2011, 25 Feb 2011; Recent Trends in Administrative Law. Wellington, New Zealand: Public and Administrative Law Conference, 18-19 Feb 2010.

20 Wiąże się to z koniecznością rozstrzygnięcia zastrzeżeń odnośnie posiadanego majątku, w tym nieruchomości. 
Niektóre sądy administracyjne rozstrzygają sprawy w konkretnym przedmiocie. Te specjalistyczne urzędy nowozelandzkiego wymiaru sprawiedliwości noszą różne nazwy, jednak wszystkie one działają w ramach jurysdykcji administracyjnej. Za przykład mogą posłużyć: urząd komisarza ds. patentów (Commissioner of Patents), sąd ds. praw autorskich (Copyright Tribunal), urząd farmacji (Pharmacy Authority) oraz sąd ds. sklepów i urzędów (Shops and Offices Tribunal). Pozostałe sądy administracyjne rozpatrują odwołania od niższych instancji. Są to np. kolegia odwoławcze od praktyk handlowych (Trade Practices Appeal Authority) czy przyznawania licencji w transporcie (Transport Licensing Appeal Authority). Do ostatniej grupy nowozelandzkich sądów administracyjnych należą te instytucje, które rozstrzygają sprawy przeciwko zwykłym decyzjom administracyjnym. Tutaj przykładami będą urząd apelacyjny do cenzury filmowej (Cinematograph Films Censorship Board of Appeal) oraz kolegium odwoławcze zagospodarowania terenu (Town and Country Planning Appeal Board) ${ }^{21}$.

\section{Podsumowanie}

Sądy administracyjne stanowią najliczniejszą oraz — z punktu widzenia ekonomicznego - najważniejszą grupę sądów w Nowej Zelandii. Jawią się one także jako ważny element wpływający na rozwój gospodarczy państwa w związku z wydawaniem licencji czy pozwoleń poszczególnym przedsiębiorstwom ${ }^{22}$. Znaczenie sądów administracyjnych w systemie prawnym i prawno-ustrojowym Nowej Zelandii stopniowo, acz znacząco rośnie. Odgrywają one istotną rolę w tym, co zostało nazwane głównym zadaniem judycjalizacji (usądowienia) postępowania sądowego (judicialising) ${ }^{23}$, tj. uprawiania administracji bez utraty jej wydajności. Należy podkreślić, iż nieliczne wady (opóźnienia, koszty sądowe oraz brak dostępu do informacji sądowej) ${ }^{24}$ niektórych sądów administracyjnych uchodzą

21 Rozróżnienia tego dokonał B.J. Cameron, radca prawny przy Departamencie Sprawiedliwości. Zob. Encyklopedia Nowej Zelandii: http://www.teara.govt.nz/en/1966/administrative-tribunals/ page-2 (dostęp: 2.10.2015).

22 Często stosuje się porównania tych instytucji do amerykańskich agencji regulacyjnych (regulatory agencies). Przykładami profesji oraz konkretnych działalności gospodarczych objętych kompetencją sądów administracyjnych jako urzędów regulacyjnych są: agencje nieruchomości, dealerzy samochodowi, usługi lotnicze, kina, mleczarnie, stacje benzynowe, sklepy, apteki czy rybołówstwo morskie. Por. przywołane wcześniej wyszczególnienie sporządzone przez B.J. Camerona.

23 Szerzej na temat tego procesu zob. J.S. Langrod, Instytucje prawa administracyjnego. Zarys części ogólnej, Kraków 2003, s. 49; J. Zimmermann, Polska jurysdykcja administracyjna, Warszawa 1996, s. 6.

${ }^{24}$ Według badań opinii publicznej, co dotyczy także innych rodzajów sądów na terenie Nowej Zelandii. Por. opracowanie S. Righarts, M. Henaghan, Public Perceptions of the New Zealand Court System: An Empirical Approach to Law Reform, „Otago Law Review” 2010, t. 12, nr 2. 
raczej za wyjątki, a nie za ich stałą właściwość. Opinia publiczna mieszkańców Nowej Zelandii darzy wielką estymą sądownictwo administracyjne. Obywatele mają świadomość konieczności, ale także przydatności jego funkcjonowania oraz powierzenia mu tak szerokich kompetencji. To bowiem m.in. dzięki wprowadzonym mechanizmom prawnym gospodarka Nowej Zelandii uznawana jest za jedną z najlepiej rozwiniętych. Ponadto państwo to co roku plasuje się w czołówce krajów o najwyższych standardach życia, a także najdogodniejszych warunkach do prowadzenia działalności gospodarczej.

\section{The administrative tribunals in the New Zealand legal system}

Summary

The article describes administrative judiciary in New Zealand, as well as its significant role in the whole legal system of the country. The development of administrative tribunals in many countries may differ, as it is associated with the constantly increasing power of any state bodies. Administrative competences do gradually rise due to the complexity of New Zealand society, but also as a response to non-compliance with social justice. In New Zealand, state carries out the functions which until recently were, or in certain countries are still, in private hands. In addition, the New Zealand administrative law system includes such institutions as the Court of Copyright, the Office of Pharmacy or the College of Appeal Land.

Keywords: New Zealand judiciary, New Zealand law, New Zealand legal system, administrative tribunals, administration, New Zealand administration, New Zealand.

\section{Bibliografia}

Bożyk S., System konstytucyjny Nowej Zelandii, Warszawa 2009.

Joseph P.A., Constitutional and Administrative Law in New Zealand, Wellington 2014.

Joseph P.A., Exploratory Questions in Administrative Law, „New Zealand Universities Law Review”, $2012 \mathrm{nr} 25$ (1).

Langrod J.S., Instytucje prawa administracyjnego. Zarys części ogólnej, Zakamycze-Kraków 2003. Palmer G., Unbridled Power: An Interpretation of New Zealand's Constitution \& Government, Oxford 1987.

Righarts S., Henaghan M., Public Perceptions of the New Zealand Court System: An Empirical Approach to Law Reform, „Otago Law Review” (2010), t. 12, z. 2.

Siekiera J., Nowa Zelandia jako regionalny wzór dobrobytu dla rozwijających się państw Pacyfiku Poludniowego, [w:] Australia, Nowa Zelandia - polityka dobrobytu, red. K.A. Kłosiński, P. Rubaj, Lublin 2014.

Zimmermann J., Polska jurysdykcja administracyjna, Warszawa 1996. 


\section{Dokumenty}

Constitutional Act 1986 (Ustawa Konstytucyjna) z 13 grudnia 1986 r. (Public Act 1986 No 114). Report of the Controller and Auditor-General on Public Consultation and Decision-making in Local Government, Wellington December 1998.

Treaty of Waitangi Act 1975 (Traktat z Waitangi) z 10 października 1975r. (Public Act 1975 No 114).

\section{Wykaz źródeł internetowych}

Encyklopedia Nowej Zelandii: http://www.teara.govt.nz/en/constitution/page-2.

New Zealand Law Society: https://www.lawsociety.org.nz/about-nzls/law-reform/public-and-administrative-law-committee.

Strona internetowa Ministerstwa Sprawiedliwości Nowej Zelandii: http://www.justice.govt.nz/courts. Strona internetowa rządu Nowej Zelandii: http://cabinetmanual.cabinetoffice.govt.nz/node/68.

\section{Pozostałe}

Carter Ross, Regulations and Other Subordinate Legislative Instruments: Drafting, Publication, Interpretation and Disallowance, Victoria University of Wellington, December 2010.

Smith Justice Lynn, The Role and Importance of Administrative Tribunals, Canadian Council of Administrative Tribunals Conference, Toronto June 21, 2004.

The New Zealand Legal System; A guide to the constitution, government and legislature of New Zealand, Ministry of Justice, Wellington 2014.

Wywiad autorki z Nyenyezi Siameja z Trybunału Waitangi, Wellington 11.03.2015. 